\title{
Studi Karakterisasi Bersahabat/Komunikatif Pada Siswa SMPN 18 Kota Jambi
}

\author{
Azizah Hanum ${ }^{1}$, Ayu Meilinda ${ }^{2}$ \\ ${ }^{1}$ SMPS Budi Pratama, Kabupaten Ogan Komering Ilir, Provinsi Sumatera Selatan \\ ${ }^{2}$ Prodi Pendidikan Fisika, FKIP, UNJA \\ 1 azizahhanum223@yahoo.com \\ 2ayumeilinda13@yahoo.com
}

\begin{abstract}
ABSTRAK
Penelitian ini bertujuan untuk menganalisa dan mendeskripsikan bagaimana karakter bersahabat/ komunikatif pada siswa SMPN 18 Kota Jambi. Penelitian ini menggunakan metode penelitian deskriptif kuantitatif. Pada penelitian ini dilakukan penyebaran angket di SMPN 18 Kota Jambi namun hanya pada dua sampel saja yaitu untuk kelas VII D dan VII H. Kemudian data tersebut dioalah dengan menggunakan program SPSS untuk dicari analisis statistik deskriptif dan klasifikasi sikap melalui rentang. Sehingga hasil penelitian yang diperoleh bahwa pada kelas VII D masingmasing memiliki persentasi $50 \%$ baik untuk siswa yang dikategorikan baik dan sangat baik. Sementara untuk di kelas VII H siswa lebih dominan berada di kategori baik dengan persentasi 80,6\% sedangkan siswa yang termasuk klasifikasi sikap sangat baik hanya 19,4\%.
\end{abstract}

Kata kunci: pendidikan karakter, bersahabat, komunikatif,

\section{ABSTRACT}

This study aims to analyze and describe how friendly / communicative the students of Jambi City Middle School 18. This study uses descriptive quantitative research methods. In this study, questionnaires were distributed at Jambi City Junior High School 18, but only in two samples, for classes VII D and VII H. Then the data was analyzed using the SPSS program to find descriptive statistical analysis and classification of attitudes through ranges. So the results of the study obtained that in class VII D each had a percentage of $50 \%$ good for students who were categorized as good and very good. While for class VII H students are more dominant in the good category with a percentage of $80.6 \%$ while students who are categorized as very good attitude are only $19.4 \%$.

Keyword : character education, friendly, communicative

\section{PENDAHULUAN}

Pada dasarnya manusia tidak terlepas dari pendidikan. Sejak manusia itu dilahirkan hingga mereka dewasa, pendidikan akan selalu menyertai mereka. Tentu saja pendidikan yang ditempuh setiap individu itu berbeda-beda. Ada yang hanya sebatas belajar mandiri, belajar dari orang lain ataupun mengenyam pendidikan di sekolah atau instansi yang ada.

Menurut Undang-Undang Sistem Pendidikan Nasional No.20 Tahun 2003 pasal 1 butir 1, pendidikan adalah: "usaha sadar dan terencana untuk mewujudkan suasana belajar dan proses pembelajaran agar peserta didik secara aktif mengembangkan potensi dirinya untuk memiliki kekuatan spiritual keagamaan, pengendalian diri, kepribadian, kecerdasaan, akhlak mulia, serta keterampilan yang diperlukan dirinya, masyarakat, bangsa dan Negara."

Di Indonesia permasalahan pendidikan terus terjadi dari tahun ke tahun. Salah satu akar permasalahan pendidikan yang ada di Indonesia yaitu kemiskinanan. Kemudian lebih lanjut dinyatakan oleh Nurdyansyah (2010) bahwa permasalahan lain yang harus dihadapi mengenai pendidikan di Indonesia itu dapat berasal dari faktor eksternal maupun internal. Lebih lanjut lagi bahwa berdasarkan hasil pengamatan di lapangan, sebagian besar waktu belajar masih di dominasi oleh guru melalui komunikasi satu arah. Hal ini dapat menyebabkan siwa menjadi kurang aktif dalam proses pembelajaran sehinggga terhambatlah 
kemampuan berpikir kritis siswa terkait informasi yang ada.

Hal ini tentu saja dapat mempengaruhi karakter dari diri seorang siswa. Raharjo (2010) mengatakan bahwa Education is basically an effort to improve human resource capacity in order to become a man with characters and live independently. Maknanya adalah bahwa pendidikan itu pada dasarnya berupa suatu upaya untuk meningkatkan kemampuan ataupu keterampilan sumber daya manusia sehingga dapat menjadikan manusia yang berkarakter dan hidup mandiri.

Pendidikan sangat erat kaitannya dengan karakter. Hal ini disebabkan bahwa pada umumnya melalui pendidikan, karakter dari seseorang itu dapat dibentuk. Maka tidak heran sering kali kita mendengar kata pendidikan karakter. Menurut Setiawati (2017), pendidikan karakter dapat dimaknai sebagai pendidikan yang berpijak dari karakter dasar manusia baik sebagai pendidikan nilai, budi pekerti, moral, watak yang tujuannya adalah untuk mengembangkan kemampuan siswa dalam menebar serta memelihara kebaikan dalam kehidupan sehari-hari. Ramdhani (2014), meyakini bahwa implementasi pendidikan karakter sangat dipengaruhi oleh lingkungan pendidikan. Tentu saja hal ini sangat berpengaruh karena seringnya terjadi interaksi antara siswa dengan lingkungannya sehingga dapat menimbulkan baik dampak positif ataupun negatif.

Salah satu karakter yang paling dominan terpengaruhi oleh lingkungan pendidikan ialah bersahabat atau komunikasi. Sehingga pada penelitian ini bertujuan untuk menganalisa bagaimana karakter bersahabat atau komunikasi para siswa SMPN 18 Kota Jambi dengan lingkungannya. Hasan (2010) menjelaskan bahwa karakter bersahabat/ komunikatif merupakan suatu tindakan yang ditandai dengan adanya rasa senang berbicara, bergaul, dan bekerja sama dengan orang lain.

Pengembangan karakter termasuk bersahabat/komunikatif dapat dilakukan melalui berbagai mata pelajaran (Hasan, 2010). Namun nilai karakter tersebut bukan diajarkan melainkan dikembangkan. Misalnya saja pada mata pelajaran fisika pada jenjang Sekolah Menengah Atas (SMA) sementara pada jenjang Sekolah Menengah Pertama (SMP) konsep fisika telah dipelajari pada mata pelajaran Ilmu Pengetahuan Alam (IPA).

Maison (2018) mengatakan bahwa fisika merupakan salah satu mata pelajraran yang sangat erat kaitannya dengan berbagai konsep ilmiah yang tanpa disadari sebagian penerapannya dapat ditemukan dalam kehidupan sehari-hari. Astalini (2018) meyatakan bahwa Implikasi sosial dari fisika memperlihatkan bagaimana pengaruh atau dampak dari ilmu fisika dalam kehidupan sosial. Banyak manfaat-manfaat sosial yang diperoleh sebagai akibat perkembangan sains dan teknologi. Oleh sebab itu guru dapat menggunakan salah satu pokok bahasan dalam fisika untuk mengembangkan nilai dan karakter siswa misalnya proses pembelajaran dengan menggunakan metode diskusi, menyampaikan pendapat dan lainnya yang dapat menimbulkan interaksi dikelas. Sehingga karakter bersahabat/komunikatif siswa dapat dikembangkan dengan baik.

\section{METODE PENELITIAN}

Pada penelitian ini menggunakan metode deskriptif kuantitatif. Yusuf (2014) mengatakan bahwa penelitian deskriptif kuantitatif merupakan jenis penelitian yang bertujuan untuk menggambarkan atau mendiskripsikan secara sistematis, faktual, dan akurat mengenai fakta tertentu. Sehingga pada jenis penelitian deskriptif kuantitatif ini akan memberikan informasi lebih mendalam dengan menggunakan tahap-tahap penelitian denga pendekatan kuantitatif.

Subjek penelitian ini adalah siswa SMPN 18 Kota Jambi terkhusus kelas VII. Adapun teknik pengambilan sampelnya adalah dua kelas yakni kelas VII D dengan jumlah siswa 30 siswa dan satu kelas lagi yakni VII H dengan jumlah siswa sebanyak 31 siswa. Maka total sampel yang digunakan adalah sebanyak 61 siswa

Instrumen pada penelitian ini ialah menggunakan angket. Peneliti melakukan survey ke sekolah yang dituju untuk kemudian dilakukan penyebaran angket pada sampel kelas penelitian yang telah ditentukan. Angket yang disebarkan merupakan angket karakter yang berhubungan dengan bersahabat atau komunikatif. Pada angket tersebut terdiri dari 25 item pernyataan yang valid dengan penggunanan 4 skala likert. Skala tertinggi yakni nilai 4 yang menyatakan sangat baik, baik memiliki nilai 3 , kemudian nilai 2 menyatakan kurang baik dan nilai 1 berarti tidak baik.

Penelitian dilakukan secara langsung artinya survei atau terjun langsung ke lapangan dengan mengikuti segala prosedur yang ada. Pada tahap awal yakni prsiapan angket karakter yang akan di bagikan kepada siswa 
tujuannya untuk menganalisis bagaimana implementasi angket karakter bersahabat atau komunikatif pada siswa SMPN 18 Kota Jambi. Tidak lupa pula bahwa angket yang akan digunakan merupakan angket yang telah valid. Kemudia siapkanlah pula tinjauan pustaka serta kajian teori yang mendukung untuk memperdalam kajian atau pokok bahasan permasalahan yang akan diteliti sehingga akan diperoleh gambaran penelitian yang dilakukan.

Teknik analisis data pada penelitian ini adalah menggunakan statistik deskriptif. Tujuannya adalah untuk menggambarkan atau mendeskripsikan data yang telah diperoleh sebagai gambaran sikap siswa. Adapun yang gambaran statistic deskriptif yang akan disajikan diantaranya yaitu mean, modus, median, minimum, maksimum dan standar deviasi. Penyajian analisis data ini dilakukan dengan menggunakan program SPSS sehingga nanti akan didapatkan tabel analisis data baik itu persentase, frekuensi rata-rata dan nilai standar deiviasi.

\section{HASIL \& PEMBAHASAN}

Adapun hasil penelitian berupa data statistik deskriptif masing-masing kelas baik untuk kelas VII D maupun VII H SMPN 18 Kota Jambi adalah sebagai berikut :

Tabel 1. Statistik Deskriptif Nilai Karakter Bersahabat/Komunikatif Kelas VII D

\begin{tabular}{lr}
\hline Mean & 80.2333 \\
\hline Median & 81.0000 \\
\hline Mode & 83.00 \\
\hline Std. Deviation & 6.53734 \\
\hline Minimum & 64.00 \\
\hline Maximum & 92.00 \\
\hline
\end{tabular}

Tabel diatas merupakan hasil analisis penyajian data statistik deskriptif mengenai nilai karakter bersahabat/komunikatif untuk kelas VII D. Data diatas didapat setelah dilakukannya penyebaran angket karakter bersahabat/komunikatif kepada siswa. Selanjutnya siswa akan mengisi pernyataanpernyataan yang berkaitan dengan indikato bersahabat/komunikatif dengan jujur sesuai dengan apa yang mereka alami dan rasakan. Angket dengan 25 pernyataan inilah yang dijadikan acuan untuk menganalisis implementasi karakter bersahabat/komunikatif pada siswa SMPN 18 Kota Jambi.Pada angket ini terdapat 4 lickert yakni sangat baik skor maksimum 4, baik skor 3, kurang baik skor 2, dan tidak baik skornya adalah 1 . Maka untuk membuat skor tersebut menjadi nilai dengan cara skor yang diperolah dibagi dengan skor maksimal kemudian dikalikan dengan 100 . Setelah format nilai didapatkan, kemudia nilai ini akan di olah di program SPSS untuk di cari mean, modus, median, standar deviasi, minimum serta maksimum. Maka hasilnya akan tampak pada tabele 1 .

Mean merupakan nilai rata-rata, untuk kelas VII D diperoleh nilai mean sebesar 80,233 . Kemudian ada median atau nilai tengah yaitu 81 , modus atau nilai yang sering muncul ini biasanya ditandai dengan lebih banyaknya jumlah frekuesi. Standar deviasi merupakan nilai statistik yang berperan dalam menentukan penyebaran data, artinya jika dalam suatu sampel standar deviasinya semakin besar maka akan semakin beragam data dari sampel tersebut. Pada table 1 nilai standar deviasi menunjukkan 6, 53734. Selain itu ada nilai minimum dan maksimum. Minimum merupakan nilai terendah yang ada pada suatu sampel, untuk tabel 1 yakni kelas VII memiliki nilai minimum 64 sedangkan nilai maksimum atau kebalikan dari minimum yaitu nilai tertinggi diperoleh sebesar 92 .

Oleh karena tujuan penelitian ini adalah untuk menganalisis bagaimana implementasi karakter bersahabat/komunikatif pada siswa SMPN 18 Kota Jambi, maka hal ini tidak cukup jika hanya dilakukan analasis melalui data statistik deskriptifnya saja. Maka dibuatlah tabel klasifikasi sikap bersahabat/komunikasi kelas VII D seperti terlihat pada tabel 2 (tabel dibawah ini).

Tabel 2

Klasifikasi Sikap Bersahabat/Komunikatif Kelas VII D

\begin{tabular}{cccc}
\hline Rentang & $\begin{array}{c}\text { Klasifikasi } \\
\text { Sikap }\end{array}$ & Jumlah & Persentase \\
\hline $25-43,75$ & Tidak Baik & 0 & 0 \\
\hline $43,76-$ & Kurang Baik & 0 & 0 \\
62,5 & & & \\
\hline $62,51-$ & Baik & 15 & $50 \%$ \\
81,25 & & & $50 \%$ \\
\hline $81,26-$ & Sangat Baik & 15 & \\
100 & & & \\
\hline
\end{tabular}

Untuk lebih memudahkan dalam hal menganalisis bagaimana implementasi karakter bersahabat/komunikatif pada siswa SMPN 18 Kota Jambi baik kelas VII D dan VII H maka perlu dibuat kategorinya masing-masing. Likert pada angket bisa dijadikan acuan atau pedoman dalam membuat kategori atau 
klasifikasi sikap. Seperti yang disajikan pada tabel 2 ada 4 klasifikasi sikap yaitu tidak baik, kurang baik, baik, dan sangat baik. Kemudian ada rentang yang berfungsi sebagai nilai interval angket karakter. Setiap rentang mewakili satu kategori atau klasifikasi sikap. Seperti sikap tidak baik itu berada pada rentang $25-43,75$, sikap kurang baik pada $43,76-$ 62,5 , baik pada rentang $62,51-81,25$, sangat baik berada di antara rentang 81,26-100.

Kemudian bisa diperhatikan ada kolom jumlah, disana menyatakan bahwa banyaknya siswa yang dikategorikan di salah satu klasifikasi sikap. Banyaknya responden atau siswa itu tergantung dari junlah sampel yang di teliti. Untuk di kelas VII D terlihat ada 15 siswa yang dikategorikan baik dan ada 15 siswa juga yang dikategorikan sangat baik. Ini menunjukkan bahwa seluruh siswa kelas VII D SMPN 18 Kota Jambi sudah baik dalam memiliki jiwa karakter bersahabat/komunikatif dengan persentasi siswa yang tergolong baik dan sangat baik adalah masing-masing sebesar $50 \%$. Untuk itu saran kepada guru agar terus mengembangkan pendidikan karakter sepeti karakter bersahabat/komunikatif.

Tabel 3. Statistik Deskriptif Nilai Karakter Bersahabat/Komunikatif Kelas VII H

\begin{tabular}{lr}
\hline Mean & 76.4516 \\
\hline Median & 75.0000 \\
\hline Mode & 72.00 \\
\hline Std. Deviation & 6.84027 \\
\hline Minimum & 65.00 \\
\hline Maximum & 94.00 \\
\hline
\end{tabular}

Selanjutnya untuk data yang disajikan pada tabel 3 yaitu data statistic deskriptif nilai karakter bersahabt/komunikatif Kelas VII $\mathrm{H}$. JIka kita bandingkan dengan tabel 1 yaitu sampel pada kelas VII D, angka statistik deskriptif pada kelas A lebih rendah atau dibawah dari kelas VII D.Terlihat disana nilai mean atau rata-rata kelas 76.4516 , kemudian untuk median sebesar 75 dan modus 72 . Jika dibandingkan nilai standar deviasinya maka kelas VII H memiliki nilai standar deviasi lebih besar atau tinggi daripada kelas VII D yaitu sebesar 6.84027. hal ini menunjukkan bahwa penyebaran data pada kelas VII H lebih beragam. Selanjutnya untuk nilai minimum sebesar 65 dan maksimum sebesar 94 yakni lebih tinggi dari kelas VII D. Selanjutnya agar dapat dianalisis lebih baik lagi maka perhatikan tabel dibawah ini yaitu tabel 4 .
Tabel. 4

Klasifikasi Sikap Bersahabat/Komunikatif Kelas VII H

\begin{tabular}{cccc}
\hline Rentang & $\begin{array}{c}\text { Klasifikasi } \\
\text { Sikap }\end{array}$ & Jumlah & Persentase \\
\hline $25-43,75$ & Tidak Baik & 0 & 0 \\
\hline $\begin{array}{c}43,76- \\
62,5\end{array}$ & Kurang Baik & 0 & 0 \\
\hline $62,51-$ & Baik & 25 & $80,6 \%$ \\
81,25 & & & \\
\hline $81,26-$ & Sangat Baik & 6 & $19,4 \%$ \\
100 & & & \\
\hline
\end{tabular}

Jika dibandingkan antara kelas VII D dengan kelas VII H maka berdasarkan tabel 4 yaitu klasifikasi sikap bersahabat/komunikatif kelas VII H maka keduanya memiliki persamaan yaitu tidak adanya siswa yang masuk kedalam kategori klasifikasi sikap tidak baik dan kurang baik. Ini menunjukkan hal yang baik dan positif. Pada tabel diatas banyaknya siswa yang tergolong sikap baik sebanyak 25 siswa dengan tingkat persentase sebesar $80,6 \%$ dan yang termasuk sangat baik ada 6 siswa dengan persentase $19,4 \%$.

\section{KESIMPULAN \& SARAN}

Berdasarkan data dari statistik deskriptif dan pengklasifikasian sikap tadi, maka dapat dikatakan bahwa baik siswa kelas VII D dan VII $\mathrm{H}$ termasuk siswa yang memiliki jiwa karakter bersahabat/ komunikatif. Selanjutnya tugas guru di sekolah yang bersngkutan diharuskan untuk dapat terus mengembangkan pendidikan karektir ini. Guru tidak harus mengubah pokok bahasan akan suatu materi pelajaran melainkan guru harus bisa mengembangkan nilai-nilai karakter dengan menggunkan materi atau pokok bahasan tersebut.

\section{DAFTAR PUSTAKA}

Astalini, Dwi Agus Kurniawan, Sumaryanti. 2018. Sikap Siswa Terhadap Pelajaran Fisika Di Sman Kabupaten Batanghari. Jurnal Ilmu Pendidikan Fisika. 3(2), 5964.

Hasan S Hamid. 2010. Penguatan Metodologi Pembelajaran Berdasarkan Nilai-nilai Budaya Untuk Membentuk Daya Saing dan Karakter Bangsa. Jakarta : Kementrian Pendidikan Nasional Badan Penelitian dan Pengembangan Pusat Kurikulum. 
Maison, Dwi agus Kurniawan, Lintang Rofiatus S. Holihah. 2018. Deskripsi Sikap Siswa Sma Negeri Pada Mata Pelajaran Fisika. Edusains, 10(1), 160-167 Nurdyansyah. 2010. Pengaruh Strategi Pembelajaran Aktif Terhadap Hasil Belajar Pada Mudrasah Ibtidaiyah. Penelitian dan Pengembangan Pusat Kurikulum.

Raharjo S Budi. 2010. Pendidikan Karakter Sebagai Upaya Menciptakan Akhlak Mulia. Jurnal Pendidikan dan Kebudayaan, 16(3), 229-237.

Ramdhani M Ali. 2014. Lingkungan Pendidikan dalam Implementasi Pendidikan Karakter. Jurnal Pendidikan Universitas Garut. 08(01), 28-37.

Setiawati Nanda Ayu. 2017. Pendidikan Karakter Sebagai Pilar Pembentukan Karakter Bangsa. Prosiding Seminar Nasional Tahunan Fakultas Ilmu Sosial Universitas Negeri Medan. 1(1), 348352.

Yusuf Muri. 2014. Metode Penelitian : Kuantitatif, Kualitatif, dan Penelitian Gabungan. Jakarta : Kencana. 